\section{Husk pasientens individuelle plan}

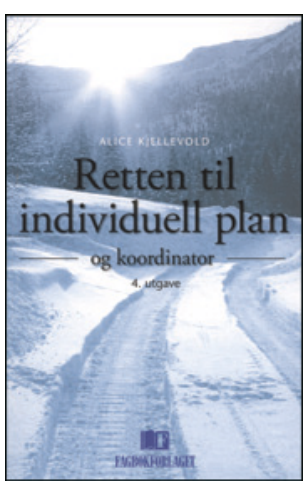

Alice Kjellevold

Retten til individuell plan og koordinator

4. utg. 118 s. Bergen: Fagbokforlaget, 2013.

Pris NOK 299

ISBN 978-82-450-1422-8

Målgruppen er dem som arbeider i helse- og sosialtjenesten i kommunene, i NAV og i spesialisthelsetjenesten. Individuell plan er et viktig verktøy eller virkemiddel for å sikre at den enkelte pasient får relevant medisinsk behandling og sosiale tjenester på en helhetlig og sammenhengende måte.

Boken gir verdifull kunnskap til personer som selv har behov for individuell plan, deres pårørende og de organisasjonene de er i kontakt med. Dessuten er den rettet mot studenter innenfor helseog sosialfag på universiteter og høgskoler.

Forfatteren redegjør for hvem som har rett til individuell plan, hvem som er ansvarlig for å utarbeide en slik plan, hvilke krav som stilles til innholdet i planen, og hvilke krav som stilles til samarbeid og koordinering. Videre redegjør hun for pasientens, brukerens og pårørendes rett til å medvirke når individuell plan skal utarbeides. Dessuten beskrives kommunens og spesialisthelsetjenestens plikt til å legge til rette for brukermedvirkning. Forfatteren viser også hvilke muligheter pasient og bruker har til å få overprøvd manglende utarbeidelse av individuell plan.

Boken er kortfattet og enkel å forstå selv om teksten hovedsakelig er juridisk. Likevel kan man som leser føle at det blir en del gjentakelser. Omslaget er tiltalende, og boken kan brukes som oppslagsbok ved hjelp av innholdsfortegnelsen, men et stikkordregister hadde nok også vært en fordel. Litteraturlisten er fyldig og omfatter ulike publikasjoner på området, offentlige dokumenter, lover og forskrifter. Disse referansene viser vei til supplerende lesning og fordypning. En tabell eller figur som illustrerer hovedaktørene på dette området, ville hjulpet den uinnvidde leseren til å få mer oversikt og se sammenhenger. Det gjelder blant annet forbindelsene mellom hvem som har rett til individuell plan, hvilke etater og organisasjoner som har plikt til å tilrettelegge for de respektive typer plan - og hvor de juridiske hjemlene finnes for de ulike formene for individuell plan.

Det er ingen tvil om at boken er relevant for leger og annet helsepersonell som vektlegger helhetlig behandling og (re)habilitering for sine pasienter. Likevel er det sannsynlig at den vil bli mest brukt av ansatte som har sosialfaglige, juridiske og trygdemedisinske oppgaver i helse- og sosialtjenesten og i NAV.

\section{Gunnar Tellnes}

Professor, Institutt for helse og samfunn

Universitetet i Oslo

\section{Interessant om «omvendt» partnervold}

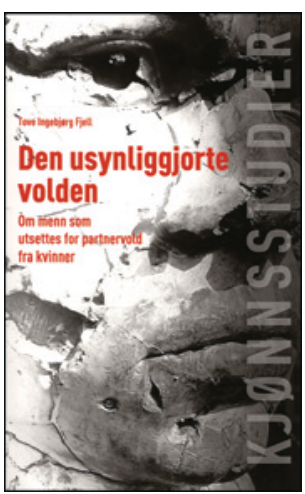

Tove Ingebjørg Fjell

Den usynliggjorte volden

Om menn som utsettes for partnervold

fra kvinner. 168 s, ill. Trondheim: Akademika

forlag, 2013. Pris NOK 270

ISBN 978-82-519-2893-9

Boken tilhører serien Kjønnsstudier, der det tidligere er utgitt fem bøker om forskjellige emner i kjønnsrolleperspektivet. I forlagets presentasjon av serien understrekes at den er tverrfaglig og har som siktemål å bidra til en utdypende forståelse av kjønn og kjønnsforhold $\mathrm{i}$ vår tid.

Forfatteren er professor i kulturvitenskap ved Institutt for arkeologi, historie, kultur- og religionsvitenskap ved Universitetet i Bergen. Hennes intensjon er å belyse en lite påaktet del av vold mellom det som internasjonalt er betegnet som «intimate partners», i denne sammenheng menn som utsettes for vold fra kvinner i heteroseksuelle relasjoner. Det gjør hun med fyldige teoretiske avsnitt som refererer foreliggende studier på området, $\mathrm{i}$ tillegg til ditto fyldig beskrivelse av egen studie med kvalitativ metodikk over 11 menn som har vært utsatt for slik vold. Målgruppen er ganske vid, og forfatterens eksplisitte siktemål er å bygge ned en svært ensidig oppfatning i samfunnet om mannen som partnervoldsutøver, og kvinnen som partnervoldsutsatt.

Språket er klart med akademisk stil i de teoretiske delene og med en mer åpen hverdagslig beskrivende tilnærming av intervjuobjektenes fortellinger. Når det gjelder empiriske studier over partnervold generelt, refereres de interessante funnene i en norsk undersøkelse fra 2005, der omtrent like mange menn som kvinner oppga å ha vært utsatt for fysisk makt fra partneren. Samtidig understrekes det at slik vold mot menn generelt er klart mildere enn mot kvinner. Det vises for øvrig på en grei måte til relevante statistikker fra Statistisk sentralbyrå over en mye lavere andel hos kvinner når det gjelder alvorlig vold og til dels også andre forbrytelser, bortsett fra vinning.

Forfatteren er opptatt av å vise de kjønnsstereotyper som preger allmennhetens og til dels både justis- og hjelpeapparatets holdning til menn som er ofre for denne typen «omvendt» partnervold, herved både latterliggjøring og avvisning.. Forfatteren knytter dette til den såkalte maskulinitetsforskningen, og refererer blant annet på en interessant måte til fire typer maskulinitet, henholdsvis «hegemonisk, underordnet, marginalisert og medvirkende» sådan.

For leger spesielt kan boken være av interesse i forståelse og eventuelt terapeutisk tilnærming til menn som presenterer slike problemer.

Pål Hartvig

Overlege, Kompetansesenter for sikkerhets-, fengsels- og rettspsykiatri Oslo universitetssykehus 